\title{
ORGANIZATIONAL AND PEDAGOGICAL TERMS OF USING CREATIVE LEARNING AT COURSES OF IMPROVING QUALIFICATION OF PEDAGOGICAL STAFF
}

\author{
Pozilova Shakhnoza Khaydaraliyevna, \\ Tashkent University of Information Technologies under \\ the name Mukhammad al-Kharazmi \\ E-mail: informatikpazilova@mail.ru \\ informatikpozilova@gmail.com
} http://dx.doi.org/10.26739/2573-5616-2018-3-1-7

Abstract: The article considers the main organizational and pedagogical conditions for the technology of creative learning. In addition, the author gives the idea of the essence of creative learning, presents a comparative characteristic of traditional and creative education.

Key words: creativity, creative learning, organizational and pedagogical conditions, creative competence, traditional and creative education, educational-methodical complex, thematic plan, technological map, the method "Sinkwein".

\section{Introduction}

ne of the global challenges of innovative development in the world is to create the conditions for people to develop creative abilities, namely, openness to new experiences, the ability to find solutions in unusual situations, a creative attitude to reality, the ability and readiness for reasonable risk, continuous improvement and professional mobility. The transition to a new type of socio-economic development is taking place: the center of gravity of production is rapidly moving from material to spiritual factors - knowledge, information, creativity.

The National Program for the Training of Personnel of the Republic of Uzbekistan focuses on "the formation of a new generation of cadres with a high general and professional culture, creative and social activity, the ability to independently orient themselves in social and political life, capable of posing and solving problems for the future." Large-scale changes in the Republic of Uzbekistan, which open great prospects for our country in the world educational space, the growth of modern information technologies, the development of global telecommunication systems require 
creative preparation of a person for life and work in the information society. Adapting to these rapid innovations of the modern world, to prepare the younger generation for life in a constantly renewed society, to make it capable of active creative participation in modernization is one of the professional tasks of the computer science teacher.

Creativity more and more enters into the daily practice of professional activity and becomes the main for the development of competitiveness not only of individual enterprises, but also of the country's economy.

\section{Previous Research}

The economic development of the industry, in particular, and the country as a whole, depends on the use of creative abilities of human resources. The importance of this quality, as well as its development for specialists in any field of activity, is noted by R. Florida, S. Lapasev. In their studies, they show that the success of an innovative economy directly depends on creative people and clarifies that society needs to expand creative professionals.

Today the formation of creative specialists is one of the main tasks of the education system of modern society. Achievement of the task is possible only with the use of an adequate goal of the creative teaching method, which involves each participant of the educational process in an active creative information and communication process, allows creating conditions for the awareness, creation and effective application of new knowledge.

Under creative training, AI Ostroumov and OF Ostroumova understand the organization of such creative activity, as a result of which it becomes possible to create new creative products by subjects of educational activity, which is distinguished by novelty and originality of the solution, i.e. activity, capable of satisfying the need of the individual in self-education and selfexpression of creative qualities. At the same time, the main goal of creative learning is to reveal the creative potential and transform the personality into an active and creative person.

\section{Comparative characteristics of traditional and creative teaching}

The essence of creative learning is that the learning process is organized in such way that not only all learners are involved in the process of cognition through the disclosure of creative abilities, but they have the opportunity to understand and reflect on what they know, think and can do.

For a more complete understanding of the essence of creative learning, we presented a comparative characteristic of traditional and creative learning (Table 1). 


\section{Table 1. Comparative characteristics of traditional and creative teaching}

\begin{tabular}{|l|l|l|}
\hline Criteria & Traditional Learning & Creative Learning \\
\hline $\begin{array}{l}\text { The purpose of } \\
\text { training }\end{array}$ & $\begin{array}{l}\text { Transfer of knowledge and } \\
\text { teachings }\end{array}$ & $\begin{array}{l}\text { Development of personal } \\
\text { creativity, formation of active } \\
\text { citizenship }\end{array}$ \\
\hline $\begin{array}{l}\text { Teacher } \\
\text { Activities }\end{array}$ & $\begin{array}{l}\text { Active, aimed at transferring } \\
\text { knowledge }\end{array}$ & $\begin{array}{l}\text { Active, is aimed at creating } \\
\text { comfortable conditions for the } \\
\text { development of student } \\
\text { creativity }\end{array}$ \\
\hline $\begin{array}{l}\text { Activity of the } \\
\text { student }\end{array}$ & $\begin{array}{l}\text { Passive (listens, writes, } \\
\text { answers questions) }\end{array}$ & $\begin{array}{l}\text { Active, aimed at finding a } \\
\text { new }\end{array}$ \\
\hline Forms of training & Frontal & Group and individual \\
\hline $\begin{array}{l}\text { Teaching } \\
\text { methods }\end{array}$ & Verbal, visual & Problematic, project, research \\
\hline $\begin{array}{l}\text { Means of } \\
\text { education }\end{array}$ & Textbooks and manuals & $\begin{array}{l}\text { Information and } \\
\text { Communication Technologies }\end{array}$ \\
\hline $\begin{array}{l}\text { Evaluation of } \\
\text { activities }\end{array}$ & Implemented by the teacher & $\begin{array}{l}\text { Self-assessment and self- } \\
\text { control }\end{array}$ \\
\hline
\end{tabular}

Comparing traditional and creative education, one can distinguish the main difference: traditional learning affects the student's intellect, and creative learning affects the personality of the learner-his thoughts, feelings, knowledge, interest and the desire for active life in an innovative society.

Based on the Resolution of the Cabinet of Ministers of the Republic of Uzbekistan No. 278 of September 26, 2012 "On measures to further improve the system of training and retraining of teachers of higher educational institutions" at the Tashkent University of Information Technology, retraining and modernization.

The aim of the Network Center is to increase the knowledge, skills and skills of staff (as well as teachers of higher education) in higher education systems for relevant professional activities, taking into account the changing needs of society, and training in retraining.

To achieve this goal, the Center performs the following tasks:

- Study of the needs of higher education institutions, identification of directions for retraining and advanced training using the capabilities of TUIT;

- Resolution of the Cabinet of Ministers of the Republic of Uzbekistan of February 16, 2006 No. 25 "Development of training programs and programs on the issues of retraining and upgrading of the pedagogical staff of the university; Introduction of modern pedagogical and information technologies in the process of retraining and advanced training;

- development of teaching aids, electronic textbooks, didactic instruments and handouts for students; 
- attraction of qualified personnel from research institutes, industrial enterprises and other higher educational institutions to the educational process;

- systematic monitoring of students' knowledge and use of impartiality;

- creating the necessary conditions for students to read and live;

- search for opportunities for extrabudgetary funds through educational services;

- organization of scientific-practical conferences and seminars;

- Establishment of retraining of teachers and masters of production of PTA institutions.

- 6 training courses are conducted in the Network Center

- Of these, four for higher education institutions:

- Informatics and information technologies;

- Telecommunication technologies;

- Computer engineering;

- Software development.

\section{Research Method}

The structure of curricula at the course "Computer Science and Information Technology":

Table 2. Training module for the course "Informatics and Information Technology"

\begin{tabular}{|l|l|l|}
\hline № & Training module & Total point \\
\hline & $\begin{array}{l}\text { The basis of normative and legal } \\
\text { education of higher education }\end{array}$ & 14 \\
\hline $\begin{array}{l}\text { Advanced teaching technologies and } \\
\text { pedagogical skills }\end{array}$ & 44 \\
\hline $\begin{array}{l}\text { The use of communication } \\
\text { technologies in the educational } \\
\text { process }\end{array}$ & 28 \\
\hline Practical foreign language & 44 \\
\hline $\begin{array}{l}\text { Basics of systematic analysis and } \\
\text { decision-making }\end{array}$ & 28 \\
\hline Special items & 88 \\
\hline
\end{tabular}

The thematic plan, reflecting the content of the discipline (the list of topics) structured according to the types of training sessions and indicating their volumes in accordance with the curriculum, is given in Table 2. The topic of the topic is the second module "Innovative educational technologies and the competence of the teacher". At the same time, we recommend the thematic planning of this module recommended for creative learning, without violating the percentage ratio of the hours allocated for this module. 
Table 3.Thematic plan for the creative teaching of informatics teachers in the courses of advanced training and retraining

\begin{tabular}{|l|l|l|l|l|l|}
\hline № & Theme total & lecture & practice & Self-study \\
\hline 1 & $\begin{array}{l}\text { Innovation. Novation. } \\
\text { Innovative } \begin{array}{r}\text { economy. } \\
\text { Innovations in education. } \\
\text { Innovative education. }\end{array}\end{array}$ & 2 & 6 & \\
\hline 2 & $\begin{array}{l}\text { Creativity and creativity. The } \\
\text { role of creative people in the } \\
\text { development of innovative } \\
\text { economy. Criteria of creativity. } \\
\text { Stages of creativity development }\end{array}$ & 40 & 4 & 2 \\
\hline 3 & $\begin{array}{l}\text { Competent approach: essence, } \\
\text { methods and means. } 12\end{array}$ & 4 & 6 & 2 \\
\hline & Total: & 30 & 10 & 16 & 4 \\
\hline
\end{tabular}

We conduct lessons on the module "Innovative educational technologies and pedagogical competence" for all training courses. One lecture and two practical exercises are devoted to the development of the creativity of a teacher at higher educational institutions.

\subsection{Conditions for the implementation of the creativity}

To the organizational and pedagogical conditions for the implementation of the creative we attributed:

1) orientation on the use of motivation to scientific and pedagogical activity as a teacher of informatics;

2) the orientation of the learning process to obtain a specific product in the form of pedagogical ideas, sites, blogs, etc., i.e. Competent-oriented work with real pedagogical projects;

3 ) the use of interactive forms of conducting classes and methods of developing creativity, as well as design thinking to create a creative learning environment;

4) continuous reflection;

5) the use of pedagogical innovations and the results of innovation to create educational and methodological support.

Let us dwell on more detail on each of the presented conditions.

The first condition.

Motivation is the driving force in any process. Therefore, for effective implementation of the method of creative learning in the courses of advanced training and retraining should be a motivation to develop their professional creativity. The teacher should encourage listeners to increase the level of development of creativity, using various ways to activate the motivational sphere. It is important that at each lesson the listener 
experiences positive emotions, so that he has self-confidence in himself, so that his interest in teaching increases.

The second condition.

As Lebedev O. notes, the competence approach is a set of general principles for determining the goals of education, selecting the content of education, organizing the educational process and assessing educational outcomes. Among these principles are the following provisions:

1) The meaning of education is the development of students' ability to independently solve problems in various spheres and activities based on the use of social experience, the element of which is their own experience.

2) The content of education is a didactically adapted social experience of solving cognitive, ideological, moral, political and other problems.

3) The meaning of the organization of the educational process is to create the conditions for the formation of the students' experience of an independent solution of cognitive, communicative, organizational, moral and other problems that make up the content of education.

4) Assessment of educational results is based on an analysis of the levels of education achieved by students at a certain stage of training.

Competent approach involves the use of the project method. To implement creative ideas, listeners, working in a group, perform pedagogical projects, presenting their methodical products in the form of presentations (PowerPoint, Ispring, etc.), mental maps in MindMap, video clips and video films, blogs, educational and methodological software products, etc. .

The third condition.

To develop creativity, it is necessary to use interactive forms of conducting classes, methods of developing creativity and design thinking to create a creative learning environment. Such a medium is characterized by the ease of the situation, the acceptance of any creative product of activity, encouragement. In such creative teaching the main place is occupied by a group of interacting teachers who, when discussing issues of interest to them and participating in discussions, stimulate and activate each other in statements and actions.

\subsection{Using creative methods for increasing creativity of informatics teachers}

An example is the use of creative methods of training in courses to enhance the qualification and retraining of cadres.

Let's give a technological map lecture on the topic "Creativity and creativity. The role of creative people in the development of innovative economy. Criteria of Creativity ". 
Table 4. Technological Map

Theme "Creativity and creativity. The role of creative people in the development of innovative economy. Criteria of Creativity".

\begin{tabular}{|c|c|}
\hline Form lesson & Lecture - discussion \\
\hline Time & 2 hour. \\
\hline Plan of lesson & $\begin{array}{l}\text { The concept of creativity. Creativity and creativity. } \\
\text { Manifestation and barriers of creativity. } \\
\text { The role of creative people in the development of innovative } \\
\text { economy } \\
\text { Creativity in professional work. } \\
\text { The manifestation of creativity - quickness, flexibility, accuracy, } \\
\text { originality of thinking, imagination, sense of humor, adherence to } \\
\text { aesthetic values, the degree of detail of the image of the problem. } \\
\text { Creating conditions for full mutual understanding and receiving } \\
\text { feedback in the development of creativity }\end{array}$ \\
\hline $\begin{array}{l}\text { The purpose of } \\
\text { the lesson }\end{array}$ & $\begin{array}{l}\text { To give basic information about creativity, criteria of } \\
\text { creativity, the role of creative people in the development of an } \\
\text { innovative society, the importance of teacher creativity in the } \\
\text { teaching and upbringing process, the laws of the development of } \\
\text { creativity }\end{array}$ \\
\hline $\begin{array}{l}\text { Actions of the } \\
\text { teacher: } \\
\text { in the form of a } \\
\text { conversation, } \\
\text { give general } \\
\text { information on } \\
\text { the plan. }\end{array}$ & $\begin{array}{l}\text { Result of training: } \\
\text { - to have an idea: about creativity, criteria of creativity, the role of } \\
\text { creative people in the development of an innovative society, the } \\
\text { importance of teacher creativity in the teaching and upbringing } \\
\text { process, the laws of creativity development; } \\
\text { - be able to: find original solutions to professional problems; } \\
\text { - have competence: } \\
\text { - at the level of key competencies, contribute to: mastering of } \\
\text { common knowledge; correctly organize their own activities and } \\
\text { joint activities with colleagues for creative self-development; } \\
\text { - at the level of basic competencies, contribute to: mastering } \\
\text { the skills of searching and processing new information and its } \\
\text { application for creative self-development in the field of professional } \\
\text { pedagogical activity; the formation of the ability to correctly } \\
\text { formulate the goals and objectives of their creative activity. }\end{array}$ \\
\hline $\begin{array}{l}\text { Teaching } \\
\text { methods }\end{array}$ & Conversation, open questions \\
\hline $\begin{array}{l}\text { Pedagogical } \\
\text { technologies }\end{array}$ & Cluster, Sinkwein \\
\hline $\begin{array}{l}\text { Means } \\
\text { teaching }\end{array}$ & Presentation \\
\hline Audience & Lecture room with multimedia computer \\
\hline
\end{tabular}

Using the Sinkwein method on "Creativity and creativity. The role of creative people in the development of innovative economy. Criteria of Creativity ".

Sinkwein (from the French cinquains, English cinquain) is a five-line verse form that originated in the United States at the beginning of the 20 th century under the influence of Japanese poetry. Later it was used for 
didactic purposes, as an effective method of developing figurative speech, which allows you to quickly get the result. A number of methodologists believe that synclines are useful as a tool for synthesizing complex information, as a cut-off for assessing the conceptual and vocabulary luggage of students.

\section{Matching rules:}

- The first line is a syncline theme, it contains one word (usually a noun or pronoun) that denotes the object or object that will be discussed.

- The second line - two words (most often adjectives or participles), they give a description of the features and properties of the object or object selected in the Sinkwein.

- The third line is formed by three verbs or verbal participles, writing the characteristic actions of the object.

- The fourth line is a phrase from four words, expressing the personal relationship of the author of the syncline to the object or object described.

- The fifth line is one word that characterizes the essence of an object or object.

Clear compliance with the rules for writing Sinkwein is not necessary. For example, to improve the text in the fourth line, you can use three or five words, and in the fifth line - two words. Variants of use of other parts of speech are also possible. For example, an adjective or a noun.

\section{Sinkwein from the point of view of pedagogy:}

Writing Sinkwein is a form of free creativity, which requires the author to find the most essential elements in the information material, draw conclusions and formulate them briefly. In addition to using Sinkwein in the lessons of pedagogy, it is also practiced to use Sinkwein as the final task for the material passed by any other discipline.Also, Sinkwein helps you to express your opinion quickly and correctly.

\section{Using creative method "Sinkwein"}

\begin{tabular}{|c|}
\hline Sinkwein on "Creativity" \\
\hline Creativity \\
\hline creative, unique, original \\
\hline develop, find, promote \\
\hline Find original solutions to professional problems \\
\hline originality \\
\hline
\end{tabular}

\section{The fourth condition.}

Reflection is the process and result of self-analysis by the subject of his consciousness, behavior, internal mental acts and states, his own 
experience, personal structures. Through reflection, a person analyzes his own actions. The mechanisms of self regulation and self-control are involved in the reflection. It is recommended to constantly ask questions such as: What did you do (result)? How did you do it (techniques, means, methods, technologies)? What difficulties arose in solving the problem? what happened best? What do you think should help consist? What new things did you acquire when solving the problem? Was the content and solution of the problem relevant to your professional interests and capabilities?

With the help of reflection, it is determined how consistent, purposeful and effective the impact was and to what extent the previously planned result is achieved.

The fifth condition.

Creation of conditions for creative learning requires a set of educational materials, created on the basis of pedagogical innovations.

We have developed a teaching and methodical complex (CMC) for creative teaching of informatics teachers at courses of advanced training and retraining includes:

1) methodical instructions for conducting lectures;

2) methodical instructions for conducting practical classes;

3) case materials for the organization of creative work;

4) control and measuring materials;

5) glossary;

The advantage of the presented CMM is the fact that the materials provide not only knowledge of the most important concepts related to creativity, but also provide an opportunity to confidently navigate in the professional sphere in the conditions of innovative education.

At present, the main goal of training is to ensure optimal conditions for the development of the individual. This means that the educator should not only give knowledge, but also do everything possible for the trainees to receive them. That is why there is a need for creative learning. The goal of the creative training of teachers of informatics in the courses of inservice training and retraining is the development of creative competence and pedagogical skills, as well as creative thinking of listeners, using creative teaching methods.

\section{Summary and Concluding Remarks}

On the basis of the use of creative methods for the development of the creativity of the teacher of informatics of higher educational institutions, conclusions and proposals are given:

- the ability to understand the innovation policy of education and the role of the creativity of the computer science teacher in the development of the country's digital economy; 
- the ability to determine the feasibility of introducing creative teaching methods into the curriculum in informatics;

- Ability to use creative methods in monitoring academic achievements of students in informatics and ICT (Information and Communication Technologies;

- the ability to plan the educational process in informatics using creative methods;

- Ability to organize study work in a group on the basis of creative teaching methods;

- the ability to use creative methods during computer science classes;

- Ability to use creative methods when organizing ICT educational projects.

\section{References}

1. Florida, R. (2002). The Rise of the Creative Class: And How it's transforming work, leisure, community and everyday life. NewYork: PerseusBookGroup.

2. Lapasev S.P. Assessment of the level of innovative development of regions on the basis of creativity // Bulletin of the OSU. 2011. № 8. P.52-56), Podberezkin AI (Podberezkin AI National Human Capital, Vol.3, Book 3. Creative Class and the Ideology of Russian Socialism - M. 2011.

3. Ostroumov AI, Ostroumova OF. Creativity and creative learning as components of the modernization of education in Russia / / Tambov: Gramota, 2013. No. 2 (28): in 2 hours C. I P. 149-153.

4. Lebedev O.E. Competence approach in education. Lebedev // School technology. 2004. - No. 5. - P. 3-12.

5. Bannov AM Learning to think together // Budkov A. S.: Materials for the training of teachers. - Moscow: INTUIT.RU, 2007. - P. 105

6. Bakhman, EV Synquists in chemistry lessons (in Russian). School: day by day. Checked on May 28, 2009.

7. LP Gimpel Pedagogical Reflexion in the Structure of Professional Activity // Personality, Family and Society: Issues of Pedagogy and Psychology: Sat. Art. by mater. I intern. scientific-practical. Conf. Part 1. Part I. - Novosibirsk: SibAK, 2010. 